\title{
Detrital sediment supply in the southern Okinawa Trough and its relation to sea-level and Kuroshio dynamics during the late Quaternary
}

\author{
Bernhard Diekmann $^{\mathrm{a}, *}$, Jana Hofmann ${ }^{\mathrm{a}, \mathrm{b}}$, Rüdiger Henrich ${ }^{\mathrm{c}}$, Dieter K. Fütterer ${ }^{\mathrm{d}}$, \\ Ursula Röhl ${ }^{\mathrm{c}}$, Kuo-Yen Wei ${ }^{\mathrm{e}}$ \\ a Alfred Wegener Institute for Polar- and Marine Research, Telegrafenberg A43, D-14473 Potsdam, Germany \\ b University Leipzig, Institute for Geology and Geophysics, Talstrasse 35, 04103 Leipzig, Germany \\ c University Bremen, Geoscience Department, P.O. Box 330440, 28334 Bremen, Germany \\ d Alfred Wegener Institute for Polar- and Marine Research, P.O. Box 120161, 27515 Bremerhaven, Germany \\ e National Taiwan University, Department of Geosciences, P.O. Box $13-318$, Taipei 106, Taiwan, ROC
}

\section{A R T I C L E I N F O}

\section{Article history:}

Received 15 November 2007

Received in revised form 16 July 2008

Accepted 5 August 2008

\section{Keywords:}

ODP Site 1202

Pacific Ocean

sediment provenance

granulometry

clay-minerals

\begin{abstract}
A B S T R A C T
During Leg 195 of the Ocean Drilling Program, Site 1202 was drilled in the subtropical northwestern Pacific Ocean beneath the Kuroshio ("Black Current") between northern Taiwan and the Ryukyu Island Arc on the northern flank of the I-Lan Ridge at $1274 \mathrm{~m}$ water depth. The upper $110 \mathrm{~m}$ of the Site 1202 section, composed of dark grey calcareous silty clay, provide an expanded record of environmental changes during the last $28 \mathrm{kyr}$. The sediments were deposited at high sedimentation rates between 3.0 and $5.0 \mathrm{~m} / \mathrm{kyr}$ and peak values of $9.0 \mathrm{~m} / \mathrm{kyr}$ between 15.1 and $11.2 \mathrm{ka}$ BP. Variations in the modes and sources of detrital sediment input, as inferred from sediment granulometry, mineralogy, and elemental XRF-scanner data, reflect changes in environmental boundary conditions related to sea-level changes, Kuroshio variability, and the climatedriven modes of fluvial runoff. The provenance data point to increased sediment supply from northwestern Taiwan between 28 and $19.5 \mathrm{ka}$ BP and from East China sources between 19.5 and $11.2 \mathrm{ka}$ BP. The change in provenance at $19.5 \mathrm{ka}$ BP reflects increased fluvial runoff from the Yangtze River and strong sediment reworking from the East China Sea shelf in the course of increased humidity and postglacial sea-level rise, particularly after $15.1 \mathrm{ka}$ BP. The Holocene was dominated by sediments that originated from rivers in northeastern Taiwan. For the pre-Holocene period prior to $11.2 \mathrm{ka} \mathrm{BP}$, low portions of sortable silt $(63-10 \mu \mathrm{m})$ show that the Kuroshio did not enter the Okinawa Trough, because of low sea-level. In turn, high proportions of sortable silt and sediment provenance from northeastern Taiwan point to strong ocean circulation under the direct and persistent influence of the Kuroshio during the Holocene. The reentrance of the Kuroshio to the Okinawa Trough was heralded by two pulses in relative current strengthening at 11.2 and $9.5 \mathrm{ka}$ BP, as documented by stepwise increases in sortable silt in the lower Holocene section. From a global perspective, environmental changes in the southern Okinawa Trough show affinities to climate change in the western Pacific warm pool with little influence of climate teleconnections from the North Atlantic realm, otherwise seen in many other marine and terrestrial palaeoclimate records from southeastern Asia.
\end{abstract}

(C) 2008 Elsevier B.V. All rights reserved.

\section{Introduction}

During Leg 195 of the Ocean Drilling Program (ODP), Site 1202 was drilled in the subtropical northwestern Pacific Ocean at the southern end of the Okinawa Trough off northeastern Taiwan (Fig. 1). Sedimentcore recovery provided a $410 \mathrm{~m}$ long sediment section, covering the last 127 kyr of the late Quaternary (Shipboard Scientific Party, 2002; Wei, 2006). The Site 1202 section thus provides a high-resolution sedimentary record in the framework of other marine records from the marginal basins of the northwestern Pacific, the South China Sea,

\footnotetext{
* Corresponding author. Tel.: +49 331288 2170; fax: +49 3312882137

E-mail address: Bernhard.Diekmann@awi.de (B. Diekmann).
}

and the northern Indian Ocean (e.g. Wang et al., 2005) that may help to understand palaeodynamics of the Asian monsoon system and the related role of oceanic processes during the late Quaternary. One important aspect at Site 1202 concerns the reconstruction of the palaeooceanographic history of the Kuroshio ("Black Current"), which forms the biggest western boundary current of the northern Pacific subtropical gyre.

In this paper, we address the palaeoenvironmental signals recorded in the detrital sediment fraction of the upper $110 \mathrm{~m}$ of the Site 1202 section, covering the last $28 \mathrm{kyr}$. The objectives are to decipher spatial and temporal variations in terrigenous sediment provenance and transportation, using mineralogical, granulometric, and geochemical tracers. The interpretation of the data provides a complex reconstruction of 

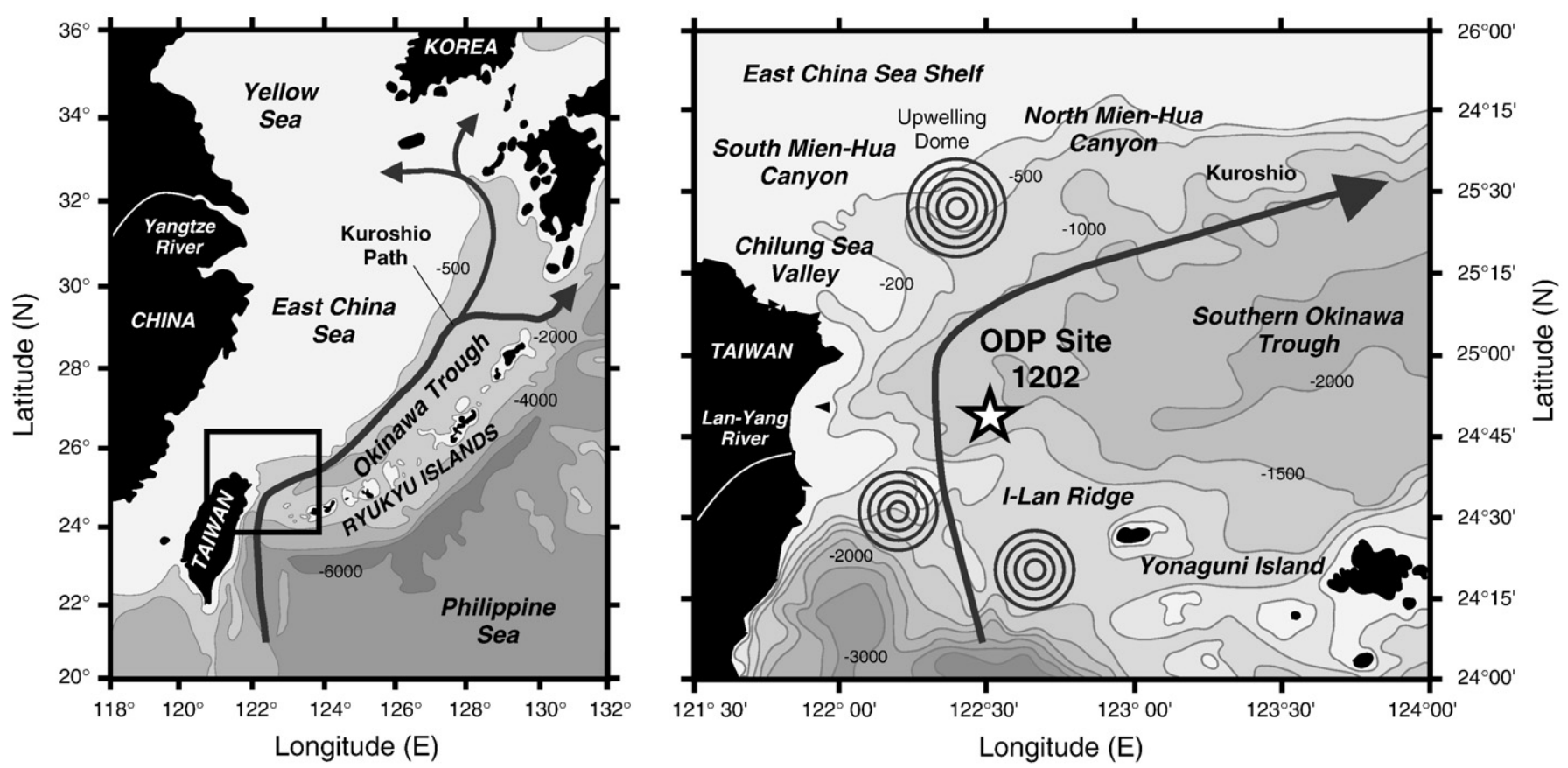

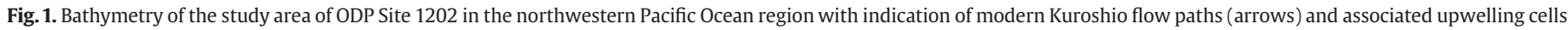
Depth intervals are shown by graded shades. The $500-\mathrm{m}$ isobath approximates the lateral position of the shelf edge.

environmental changes in the terrestrial and marine realm around the study site, taking into account Kuroshio variability, postglacial sealevel rise, changes in fluvial runoff, neotectonics, and monsoon climate variability.

\section{Regional setting}

\subsection{Site location}

Site 1202 is located at $1274 \mathrm{~m}$ water depth in the southern Okinawa Trough on the northern flank of the I-Lan Ridge $\left(24^{\circ} 48.24^{\prime} \mathrm{N}\right.$, $\left.122^{\circ} 30.01^{\prime} \mathrm{E}\right)$, which connects the northeastern tip of Taiwan with Yonaguni Island, the southernmost island of the Ryukyu Island Arc (Fig. 1). The crest of the I-Lan Ridge lies at approximately $750 \mathrm{~m}$ water depth. The southern Okinawa Trough reaches maximum water depths of about $2000 \mathrm{~m}$. Towards the northeast, it is bordered by the wide shelf of the East China Sea. The shelf break near Taiwan is dissected by several submarine channels of the Chilung Sea Valley and the MienHua Canyon system. The Ryukyu Island Arc and the I-Lan Ridge form the outer boundary of the Okinawa Trough towards the open northwestern Pacific Ocean. The Okinawa Trough represents the back-arc basin of the Ryukyu subduction system, situated at the active plate boundary between the oceanic Philippine Plate and the continental Eurasian Plate, east of the Ryukyu Island Arc (Yu and Chow, 1997).

\subsection{Climate}

The climate of the study area is determined by the East Asian Monsoon system with pronounced seasonal fluctuations in humidity, temperature, and atmospheric circulation (e.g. Lee and Chao, 2003). A low pressure cell above the central Eurasian continent during summer is associated with southeasterly winds that carry warm and moist air masses from the Pacific Ocean towards Taiwan and mainland China. During the winter season, reversed pressure gradients with prevailing northwesterly winds carry dry and cool air masses from the Eurasian continent towards the Pacific Ocean. The seasonal fluctuation of the monsoon regime strongly influences the hydrographic conditions in the East China Sea and Kuroshio circulation in the Okinawa Trough (Lee and Chao, 2003).

\subsection{The Kuroshio (Black Current)}

The Kuroshio originates in the westward flowing North Equatorial Current of the central Pacific, which is deflected towards the northeast off the Philippine Islands. The Kuroshio is an important carrier of heat and moisture from the western Pacific warm pool to the middle latitudes of the northern Pacific Ocean (Hsin et al., 2008; Andres et al., 2008). Off Taiwan, the narrow and up to 300-600 m deep-reaching flow of the Kuroshio reaches current velocities of up to $130 \mathrm{~cm} / \mathrm{s}$. Volume transport varies between 28 and $33 \mathrm{~Sv}$ ( 1 Sverdrup $=10^{6} \mathrm{~m}^{3} \mathrm{~s}^{-1}$ ) in the open Pacific east of Taiwan (Hsin et al., 2008) and on average around 18.5 Sv in the East China Sea and above the Okinawa Trough (Andres et al., 2008). Seasonal sea-surface temperature of the Kuroshio vary between $22{ }^{\circ} \mathrm{C}$ and $29^{\circ} \mathrm{C}$ (Lee and Chao, 2003).

The main part of the Kuroshio enters the Okinawa Trough northeast of Taiwan across the I-Lan Ridge (Fig. 1). In the Okinawa Trough, the Kuroshio inflow gives rise to a complexly coupled shallow and deep current system that reaches down to the sea floor (Nakamura et al., 2008). The Kuroshio axis is located over the upper continental slope of the East China Sea, revealing minor lateral shifts of the flow path through the seasons (Andres et al., 2008). The shelf edge of the East China Sea forms a barrier and site of northeastward deflection for Kuroshio flow and causes upwelling of Kuroshio Subsurface Water and the formation of eddies and cold-water domes above the northern and southern Okinawa Through that vary in intensity through the seasons (Hsu et al., 1998; Nakamura et al., 2008). The cyclonic eddies above the Mien-Hua Canyons in the southern Okinawa Trough (Fig. 1) represent important cells of water mixing by the interaction of Kuroshio waters and waters from currents of the East China Sea, flowing along the northern coast of Taiwan (Hsu et al., 1998; Hung et al., 1999).

In the deeper level of the Okinawa Trough, a southwestward directed slope countercurrent flows below 500 water depth and is directly related to seasonal Kuroshio eddy activity (Nakamura et al., 2008). In the northern Okinawa Trough, the slope countercurrent appears during summer, when eddy activity is enhanced in the southern Okinawa 
Trough. In the southern Okinawa Trough, the slope countercurrent is more stable and strongest (up to $20 \mathrm{~cm} / \mathrm{s}$ ) and mainly persists during winter-spring, when the Kuroshio front meanders in the northern Okinawa Trough and eddy activity is reduced in the surface waters of the southern Okinawa Trough. The underlying deep-water flow of the slope countercurrent can be traced as deep as $1450 \mathrm{~m}$ water depth (Chung and Hung, 2000). The location of Site 1202 at the northern foot of the I-Lan Ridge is promising for the reconstruction of Kuroshio dynamics in the past, as it is placed beneath the main jet of the Kuroshio and at the southern end of the related deep countercurrent loop.

It is assumed that during the late Pleistocene, Kuroshio activity generally was weaker than at present, as inferred from marine records off central Japan (Chinzei et al., 1987; Sawada and Handa, 1998). At the same time, the Okinawa Trough was nearly isolated from the open Pacific Ocean and the current path of the Kuroshio was totally displaced to the open Pacific Ocean, because of lower sea-level than present (Ujiie et al, 1991; Ahagon et al., 1993). The timing of the reentrance of the Kuroshio to the Okinawa Trough is still a matter of controversy and has been inferred to have taken place in distinct steps between $16 \mathrm{ka}$ and 7.3 ka BP, depending on the proxy records used (Li et al., 1997; Xu and Oda, 1999; Jian et al., 2000; Li et al., 2001; Ujiié et al., 2003; Kao et al., 2005, 2008; Li et al., 2005; Sun et al., 2005; Xiang et al., 2007).

\section{Modern detrital sediment supply}

Today, fluvial runoff from the mountain ranges of Taiwan is the main source of detrital sediment supply to the southern Okinawa Trough, resulting from high erosional gradients and heavy summer rain falls (Hsu et al., 2004). In northern Taiwan, drainage of the mountain areas is basically achieved by the Lan-Yang River, whose mouth is directly situated adjacent to the southern Okinawa Trough. Annual total sediment yield amounts to 6-9 Mt (Jeng et al., 2003; Kao et al., 2003). Parts of the fluvial suspensions are entrained and transported by the Kuroshio Current and transferred to the deep by the suction effect of the cyclonic eddies north of Taiwan (Hsu et al.,
1998). The underlying Mien-Hua Canyons represent the major conduits for particle transport to the deep and are subsequently incorporated into the slope countercurrent (Hung et al., 1999). In addition to the permanent processes of sediment supply, episodic events cause downslope sediment transport from the margins of the southern Okinawa Trough through mass wasting and density currents, triggered by earth quakes, typhoons, and heavy floods in the terrestrial hinterland (Ujiié et al., 1997; Hsu et al., 2004).

Another sediment source is the particulate load of the Yangtze River (Changjiang), delivering a total of 240-680 Mt of undissolved material to the East China Sea per year (Oguri et al., 2003, Liu et al., 2007). Small portions of the fluvial suspensions and reworked shelf sediments of Yangtze origin reach the southern Okinawa Trough through long-distant transport in the current system of the East China Sea (Liu et al., 2003). Eastward transport of Yangtze sediment plumes directly to the Okinawa Trough occurs during high river discharge in the winter season (Kao et al., 2003; Oguri et al., 2003). Otherwise, the Yangtze sediment plume usually extends southward along the East China coast and is deflected to the northeast by counter currents in the Taiwan Strait (Kao et al., 2003). There, these far-travelled particulates mix with suspensates from western Taiwan rivers (Chen, 1973; Eisma et al., 1995). Together with the sediment loads from eastern Taiwan, they eventually become trapped in the eddy system of the southern Okinawa Trough (Hung et al., 1999). The complex Kuroshio-related current structure in the southern Okinawa Trough accounts for extremely high particle fluxes that might be the highest among observations from worldwide continental margins (Hung et al., 1999; Hsu et al., 2004).

\section{Materials and methods}

This study was confined to the upper section of Hole 1202B, 0110 mbsf (metres below sea floor), which has been dated by AMS ${ }^{14} \mathrm{C}$ measurements (see Section 5). This section comprises the upper fourteen sediment cores of the hole, which were drilled with an
Linear Sed. Rates $(\mathrm{m} / \mathrm{kyr})$
$\mathrm{Ca}$

(XRF Counts)
$\mathrm{K} / \mathrm{Ti}$ Ratio (XRF Counts) $\begin{array}{cc}\text { Mica + Illite } & \text { K-Feldspar } \\ \text { (XRD 10-Å Counts) } & \text { (XRD 3.24-Å Counts) }\end{array}$
Age (ka BP)

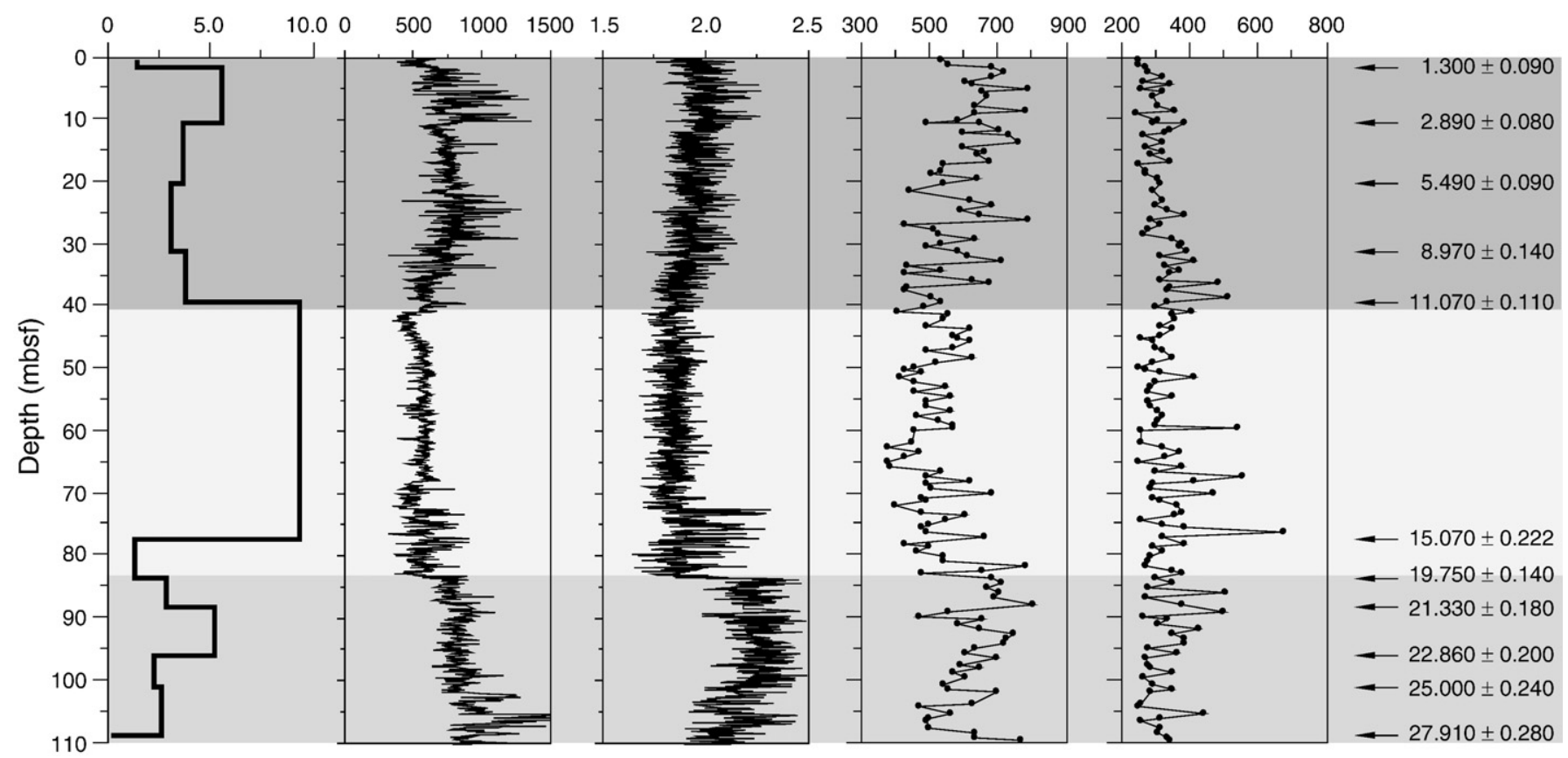

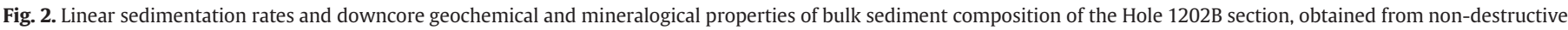

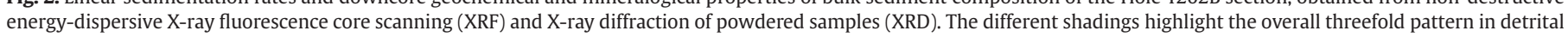
sediment composition of the Site 1202 record. Age markers are from Wei et al. (2005). 
advanced piston coring system and yielded a sediment recovery of better than $99 \%$ in the mostly $9.5-\mathrm{m}$ long cores (Shipboard Scientific Party, 2002). Below 50 mbsf, the cores are moderately disrupted by horizontal gas voids. The sediments of the section are quite uniform in composition and consist of dark grey calcareous silty clays, occasionally interspersed with $\mathrm{mm}$ - to $\mathrm{cm}$-thick calcareous sand stringers. A quantitative description of the sand layers revealed sedimentary features akin to gravitational sediment transportation, such as basal erosion, internal grain-size grading, cross ripples, and the presence of reworked remains of shallow-water organisms (Huang et al., 2005). The investigated section thus provides a late Quaternary record of hemipelagic sedimentation, temporarily affected by the episodic action of turbidity currents (Shipboard Scientific Party, 2002). Analytical work was only carried out on the hemipelagic sediment fraction, to infer temporal changes in the modes of permanent deposition of fine-grained detrital material.

Bulk geochemistry ( $\mathrm{Ca}, \mathrm{Ti}$, and $\mathrm{K}$ ) was measured on U-channels, using a non-destructive energy-dispersive X-ray fluorescence (XRF) core scanner at Bremen University, Germany. The general method and some calibration procedures are described elsewhere (Jansen et al., 1998; Röhl and Abrams, 2000). The XRF measurements were concentrated on the undisturbed silty clays. In case of the presence of voids or turbidite layers, the regular scan point was shifted for a few centimetres to the nearest silty clay unit.

Grain-size and mineralogical analyses were conducted on about 125 discrete samples. Sample spacing was $\pm 75 \mathrm{~cm}$, representing time steps between 150 and 750 years. The relative abundances of mica/illite-like minerals (10- $\AA$ phases) and potassium feldspar (3.24- $\AA$ phases), obtained from X-ray diffraction (XRD) measurements of random powder mounts, were compared with the K-signal in the XRF logs (Fig. 2).

The chemical treatment of subsamples (removal of organic carbon and carbonate) provided the detrital siliciclastic sediment fraction (Kuhn and Diekmann, 2002). It was washed through a 63- $\mu \mathrm{m}$ mesh for grain-size separation of sand from silt and clay. The fine fraction was measured with a 'Micromeritics SediGraph 5000E', providing the percentage of the so-called sortable silt, which is defined as the proportion of silt particles of the 63- to 10-micron fraction in the total $<63$-micron fraction (silt and clay). This parameter is used to infer relative variability in bottom-current strengths (Ledbetter, 1984; McCave et al., 1995; Kuhn and Diekmann, 2002). Silt and clay was separated at $2 \mu \mathrm{m}$ in settling tubes to verify the proportions of silt and clay obtained from the SediGraph measurements and to isolate the clay fraction for mineralogical analyses.

Clay mineralogy was determined semi-quatitatively by XRD measurements (on glycolated preferentially oriented clay mounts (Philips PW1820 XRD device with CoK-alpha radiation at $1600 \mathrm{~W}$, $40 \mathrm{kV}, 40 \mathrm{~mA}$ ). Sample preparation and semi-quantitative evaluation of X-ray diffractograms followed techniques explained in detail elsewhere (Ehrmann et al., 1992; Petschick et al., 1996). Mineral proportions are calculated from weighted peak areas recorded in the $\mathrm{X}$-ray diffractograms. Smectite proportions refer to expandable clayminerals, showing a peak at around $17 \AA$ After glycolation. The relative abundance of the clay-mineral groups in the clay fraction is summed to $100 \%$ using standard weighting factors as follows (Biscaye, 1965): the 17 - $\AA$ peak area for smectite, the 10 - $\AA$ peak area * 4 for illite, and the 7 -Å peak area for kaolinite and chlorite subdivided in proportion to the relative areas of their $3.57-\AA$ and $3.54-\AA$ peaks, respectively. Relative analytical precision for major clay component is 6-9\%, and 814\% for minor clay components (Ehrmann et al., 1992).

All sample specifications and data lists can be extracted from the PANGAEA data information system (www.pangaea.de).

\section{Stratigraphy and sedimentation rates}

The applied age model of the Hole 1202B section is based on AMS ${ }^{14} \mathrm{C}$ measurements of surface-water dwelling foraminifera, including Globigerinoides spp. and Orbulina universa from 10 samples between 10.88 and 109.1 mbsf and a scaphopoda from $1.92 \mathrm{mbsf}$ (Wei et al., 2005), supported by palaeomagnetic data (Richter et al., 2006). The radiocarbon ages were converted to calendar ages before present $(\mathrm{BP}=\mathrm{AD} 1950)$ and corrected for a local marine reservoir effect of 400 years (see details in Wei et al., 2005). The time scales of the

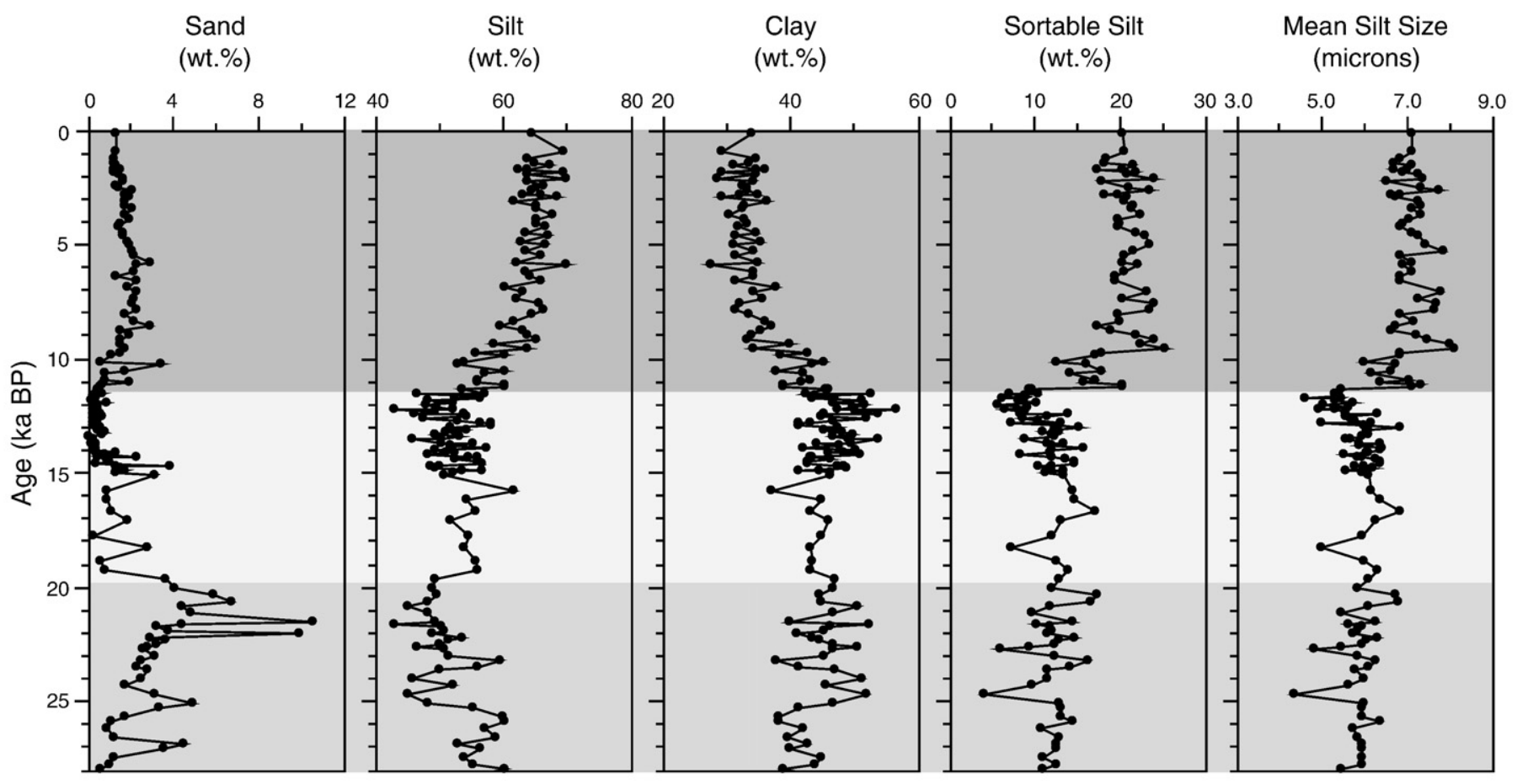

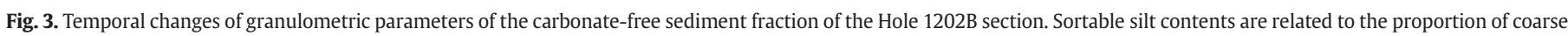
silt (63-10 microns) in the fine fraction (silt and clay). The different shadings highlight the overall threefold pattern in detrital sediment composition of the Site 1202 record. 


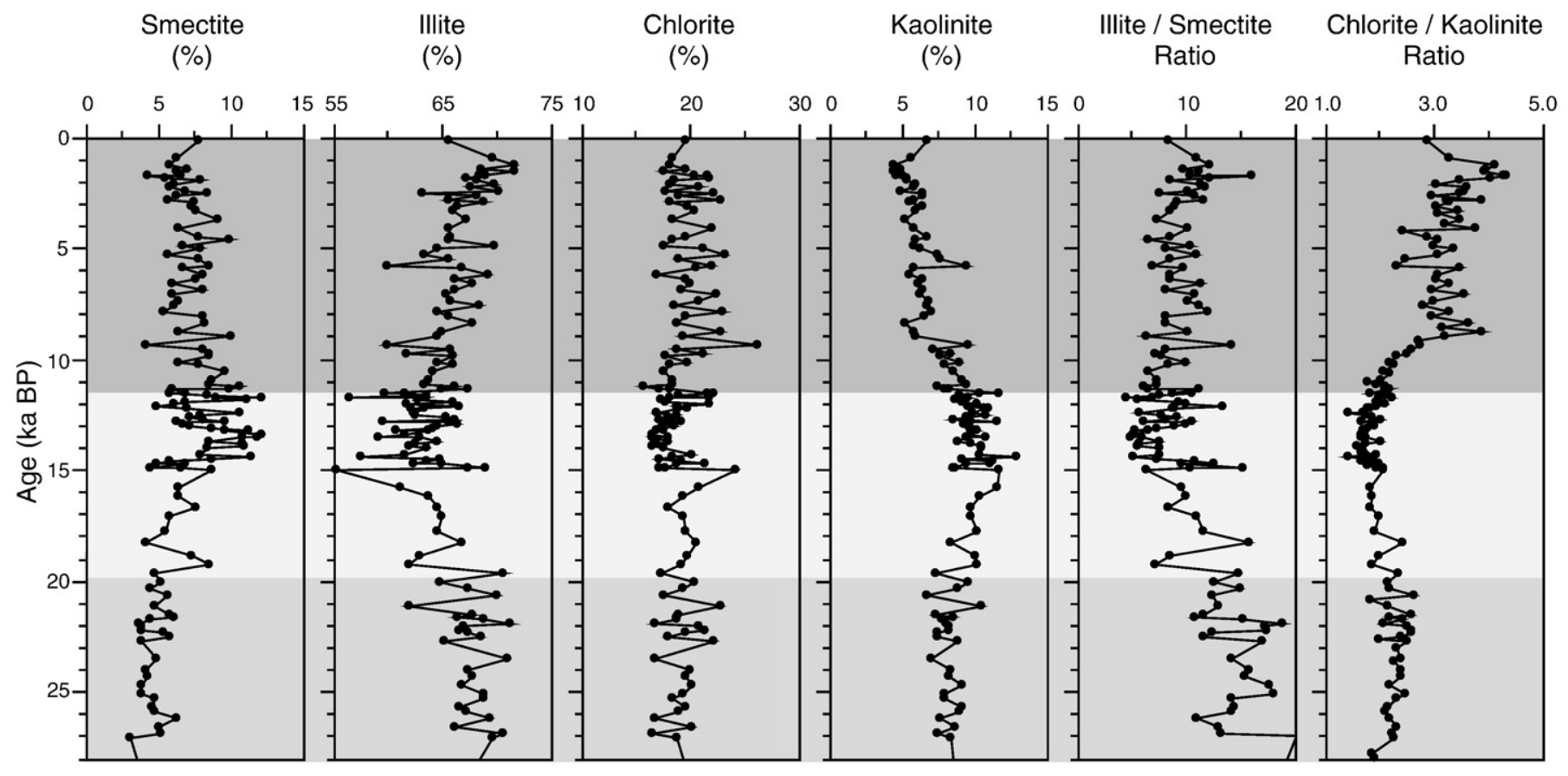

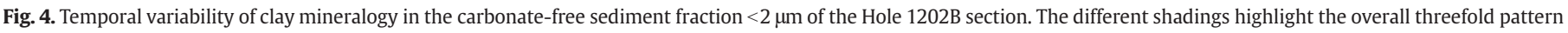
in detrital sediment composition of the Site 1202 record.

presented data points were calculated from linear interpolation between the obtained age datums. According to the linear age/depth relationship, marine deposition at Site 1202 took place at high rates of between 1.4 and $5.6 \mathrm{~m} / \mathrm{kyr}$, and reached maximum values of $9.4 \mathrm{~m} / \mathrm{kyr}$ between 15.1 and $11.1 \mathrm{ka}$ (Fig. 2). These values support the modern observation of extremely high sedimentation rates in the southern Okinawa Trough (Hsu et al., 2004).

\section{Results}

The variability of the measured parameters generally shows a threefold downhole pattern (Figs. 2-4). The upper part comprises the interval between 0 and $40 \mathrm{mbsf}$ and includes the Holocene part of the section. The middle section comprises the interval between $40 \mathrm{mbsf}$ and $84 \mathrm{mbsf}$, corresponding to the last glacial maximum and late glacial climate stage between $19.5 \mathrm{ka}$ BP and $11.2 \mathrm{ka}$ BP. Although quite uniform in composition, the middle section shows extreme contrasts in documented sedimentation rates and includes the interval with the highest values between 15.1 and $11.1 \mathrm{ka}$ BP. The lowermost section down to $110 \mathrm{mbsf}$, reaches as far as $28 \mathrm{ka}$ BP back in time.

\subsection{Downhole element distribution and its relation to the mineralogy of the bulk sediment fraction}

The distribution of the elements $\mathrm{Ca}, \mathrm{K}$, and Ti in the sediment cores of Hole 1202B, displayed by their XRF intensities, is shown in Fig. 2. Although characterized by mostly high-frequent fluctuations, the general threefold pattern of downcore variability is evident. The Ca intensities basically reflect the contents of both biogenic and detrital carbonate components, which are elevated in the upper and lower sections, as also revealed by smear-slide data (Shipboard Scientific Party, 2002). The K/Ti ratio was calculated to emphasise differences in the composition of the terrigenous detrital material. Slightly elevated $\mathrm{K} / \mathrm{Ti}$ ratios occur above $40 \mathrm{mbsf}$, while strong maxima dominate in the lowermost section interval. In comparison with bulk mineralogy, it becomes evident that the K/Ti signal is more related to the amount of mica and illite sheet silicates rather than to the amount of potassium feldspar (Fig. 2).

\subsection{Granulometry of the detrital sediment fraction}

The downhole grain-size distribution of carbonate-free sand, silt, and clay is depicted in Fig. 3. Sand makes up a minor fraction and shows increased percentages of up to $2.5 \%$ in the upper section. Low percentages of mostly $<1 \%$ follow in the middle section and increase again in the lower section with peak values of up to $10.5 \%$. The variability of silt and clay percentages shows a twofold pattern with maximum silt concentrations of around 65\% in the upper section that continuously decrease to values of around $50 \%$ below. Clay concentrations show a mirrored trend to silt contents, with low percentages of about $35 \%$ in the upper section and of around $50 \%$ below. The twofold pattern with a pronounced grain-size coarsening of the fine fraction towards the upper section is well displayed by two stepwise and

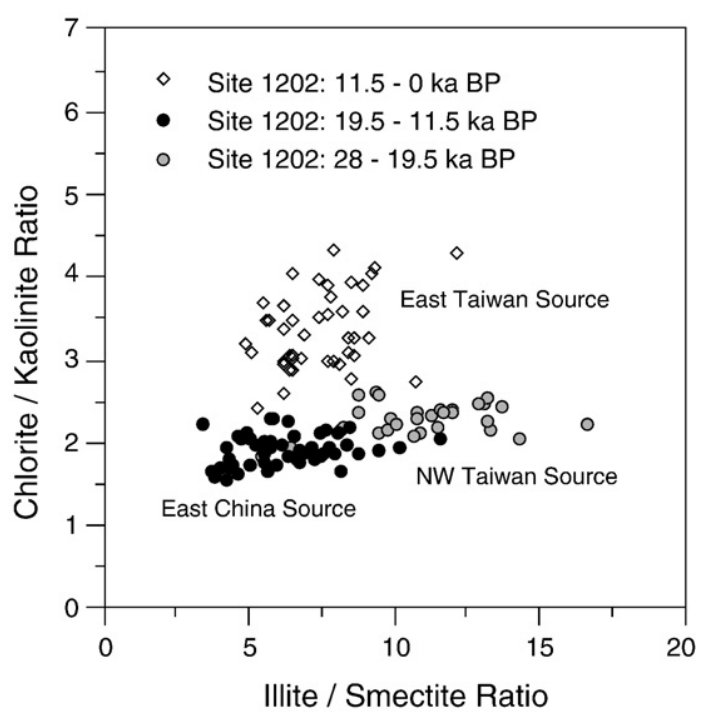

Fig. 5. Scatter plot of clay-mineral ratios in samples from the Site 1202 section. According to literature data (Table 1), clay-mineral provenance from three different source regions can be discriminated. 
concomitant increases in the amount of sortable silt and mean grainsize in the silt and clay fraction.

\subsection{Clay mineralogy}

In decreasing abundance, the clay-mineral assemblage in the Site 1202 section consists of illite (55-75\%), chlorite (15-25\%), kaolinite (5-13\%), and expandable smectite-bearing minerals (3-12\%) (Fig. 4). The downhole variability of clay-mineral distributions is best displayed by the chlorite/kaolinite and illite/smectite ratios (Figs. 4 and 5). The upper section is dominated by a clay-mineral assemblage with high chlorite/kaolinite ratios $>2.5$ and intermediate illite/ smectite values between 5.0 and 10.0. The middle section shows the low chlorite/kaolinite $(<2.5)$ and low illite/smectite values $(<10 \%)$. The lower section shows intermediate chlorite/kaolinite values in combination with maximum illite/smectite ratios (>10.0).

\section{Discussion}

In the following section, the mineralogical and geochemical data will be interpreted in terms of changes in sediment provenance. The granulometric data are used to deduce the relative vigour of Kuroshio-related ocean circulation. In the final part, changes in terrigenous sediment supply are regarded in the context of regional environmental and climatic changes (Figs. 6 and 7). In this contribution, data evaluation only considers the long-term patterns, because the quality of the applied age model does not allow constraining short-term events and cycles below millennial to centennial time resolution.

\subsection{Detrital sediment sources}

The pattern of modern particle fluxes, as outlined in Section 3, suggests that the detrital sediments of the southern Okinawa Trough originate from two major terrestrial sources, the Taiwan hinterland and mainland China, with negligible contributions from the Ryukyu Island Arc. Studies on the distribution of modern clay-mineral assemblages in the Okinawa Trough and the East Chinas Sea have highlighted the use of clay-minerals as tracers of sediment provenance. The source of terrigenous clay-minerals is mainly nourished by the large rivers from continental China and the rivers of the mountainous island of Taiwan (Aoki and Oinuma, 1974; Chen, 1973; Lin and Chen, 1983; Eisma et al., 1995; Yang et al., 2003). While aeolian contributions from mainland China play an important role for detrital fluxes in the pelagic Pacific Ocean (Rea, 1990), the supply of windborne material to the marginal seas of the northwestern Pacific is mostly masked by fluvial detrital discharge (Chen, 1978).

The mineral composition of detrital materials in the Okinawa Trough points to sediment sources from mainland China and Taiwan, and is characterized by high amounts of illite and chlorite and scarce kaolinite and smectite (Aoki and Oinuma, 1974; Chen, 1973; Lin and Chen, 1983), which is consistent with the Hole 1202B clay-mineral record. In Taiwan, illite and chlorite are abundant in the widespread slates and schists as well as in soils and Neogene to Pleistocene deposits, whereas kaolinite and smectites only occur locally (Chen, 1973; Dorsey et al., 1988). From mainland China, the Yellow River (Huang He) mostly supplies eroded material from the illite- and chlorite-rich loess province with low amounts of smectite. The suspensates from of the Yangtze River are derived from both the Tibetan Plateau and the low lands of East China (Yang et al., 2003; 2004). The solid load of the Yangtze River (Changjiang) originates from various metamorphic, igneous and sedimentary rock types and extensive podsolic to latosolic soils that, in addition to illite and chlorite, provide conspicuous amounts of kaolinite and smectite (Chen, 1973; Eisma et al., 1995). The modern distribution of kaolinite in the bottom-surface sediments of the East China Sea and the
Okinawa Trough traces the spread of fluvial sediments from East China as far as the Okinawa Trough (Aoki and Oinuma, 1974).

In order to infer clay-mineral provenance in the southern Okinawa Trough, the clay-mineral assemblages of the Site 1202 record are compared with published reference data, obtained from the study of sea-bottom sediments around Taiwan, the Okinawa Trough, and the East China Sea (Table 1). Keeping in mind the application of different methods for the semiquatitative estimation of clay-mineral proportions, it nevertheless becomes evident that basically three sediment sources can be distinguished on the basis of distinctive clay-mineral ratios (Chen, 1973; Aoki and Oinuma, 1974; Lin and Chen, 1983; Eisma et al., 1995). Sediments derived from mainland China, in particular from the Yangtze River, are characterized by relatively high amounts of the pedogenic clay-minerals kaolinite and smectite, as expressed by generally low chlorite/kaolinite and illite/smectite ratios in fluvial sediments from East China and shelf sediments of the East China Sea. Sediments from Taiwan are generally enriched in illite and chlorite. Maximum chlorite/kaolinite ratios and intermediate illite/smectite ratios indicate fluvial sediment supply from the chlorite-rich greenschist slates of the high mountain ranges of eastern Taiwan to the open Pacific and the southern Okinawa Trough. Smectite may originate from altered volcanic rocks of the coastal ranges of eastern Taiwan. Sediments from these sources are mainly delivered by the Lan-Yang River to the southern Okinawa Trough (Hsu et al., 2004). In contrast, intermediate chlorite/kaolinite and maximum illite/smectite ratios point to fluvial sediment supply from rivers of western Taiwan to the northwestern Taiwan shelf.

From the obtained clay-mineral data of the Site 1202 record, a qualitative estimate of variable sediment supply from East China, western and eastern Taiwan is indeed well expressed by the downhole fluctuations of chlorite/kaolinite ratios and illite/smectite ratios (Fig. 5). Considering the three end members, the Holocene section is clearly dominated by sediment supply from eastern Taiwan sources, which is consistent with the modern observations of fluvial drainage from the central mountain ranges. This source is indicated by a cluster of data points with high chlorite/kaolinite ratios in the scatter plot of Fig. 5. The older sediments include variable amounts of clay derived from East China (Yangtze River) and western Taiwan, as shown by the alignment of data points on a mixing line between low chlorite/ kaolinite and illite/smectite ratios towards intermediate chlorite/ kaolinite and high illite/smectite values. The temporal variation of clay-mineral ratios points to a prominent Yangtze/East China Sea shelf signal for the time interval between $19.5 \mathrm{ka}$ and $11.2 \mathrm{ka} \mathrm{BP}$, while the time before apparently was characterized by stronger sediment input from the northwestern Taiwan shelf area.

A coherent picture of changes in sediment provenance arises from variations in $\mathrm{K} / \mathrm{Ti}$ ratios in bulk sediment (Fig. 2). The potassium signal is basically related to the potassium-bearing sheet silicates, which are supplied in large amounts from the weathering products of the widespread schists and slates in Taiwan. Titanium represents another tracer of lithogenic sediment supply from the various sources, as it tends to be enriched above means of the upper continental crust in the particulate load of the Yangtze River, indicating contributions from weathered landscapes of the east China low lands (Yang et al., 2004). Thus lowest $\mathrm{K} / \mathrm{Ti}$ ratios appear in the middle section dominated by sediments from East China. Maximum K/Ti in the old part of the section are consistent with the high supply of illite-rich materials from western Taiwan. Sediment supply from northeastern Taiwan is displayed by intermediate $\mathrm{K} / \mathrm{Ti}$ values in the Holocene section.

\subsection{Sedimentary signals of regional ocean current strengths}

The grain-size distribution of lithogenic sediments in marine sediments generally depends on the granulometry of source materials, weathering, and grain-size sorting processes during particle transportation in the ocean. A provenance signal on grain-size characteristics of the 


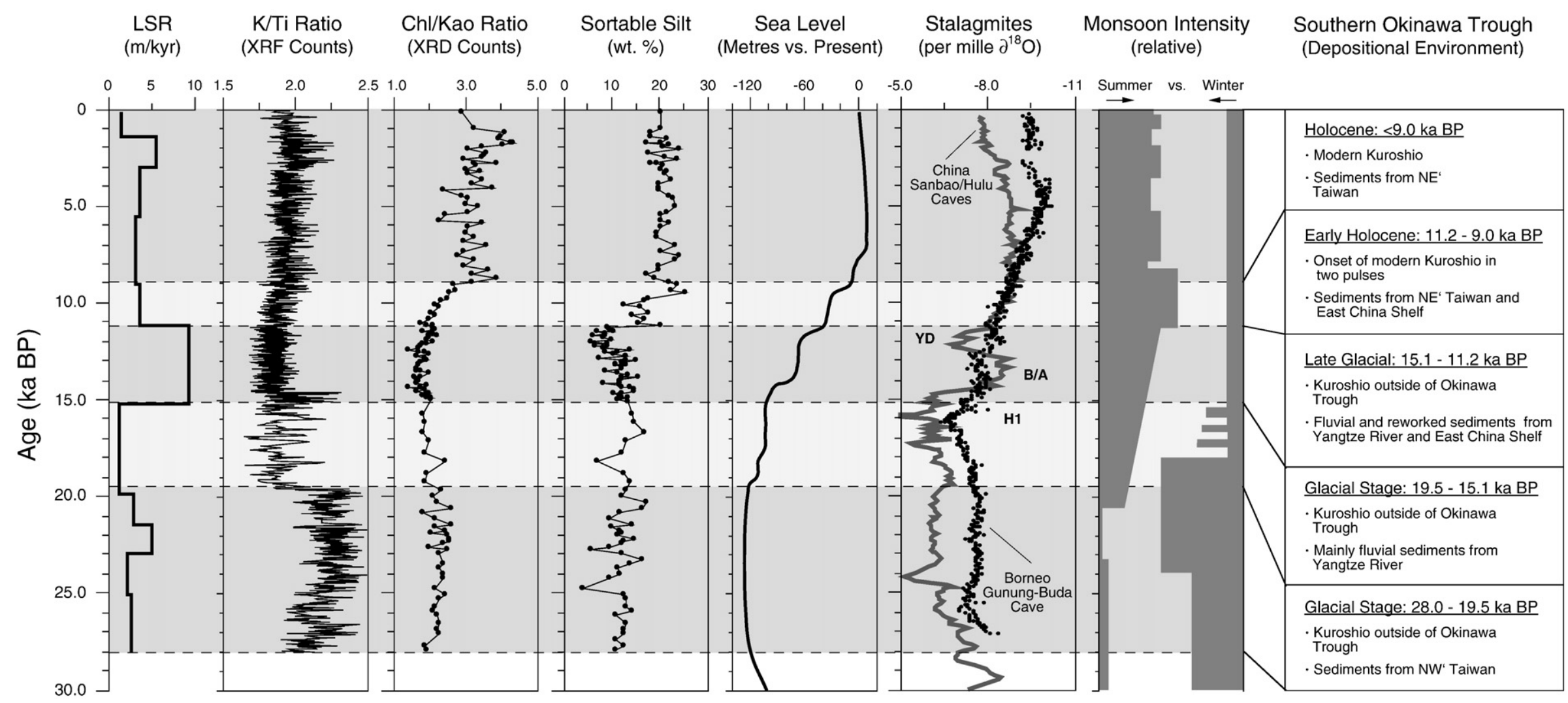

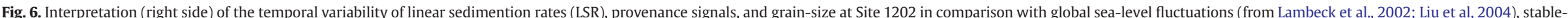

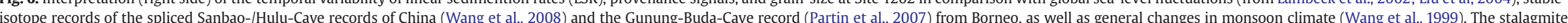
records are proxies for changes in precipitation in response to increased summer monsoon (more negative values to the right side of the scale). Abbreviations: (YD) Younger Dryas, (B/A) Bølling-Allerød, (H1) Heinrich Event 1. 


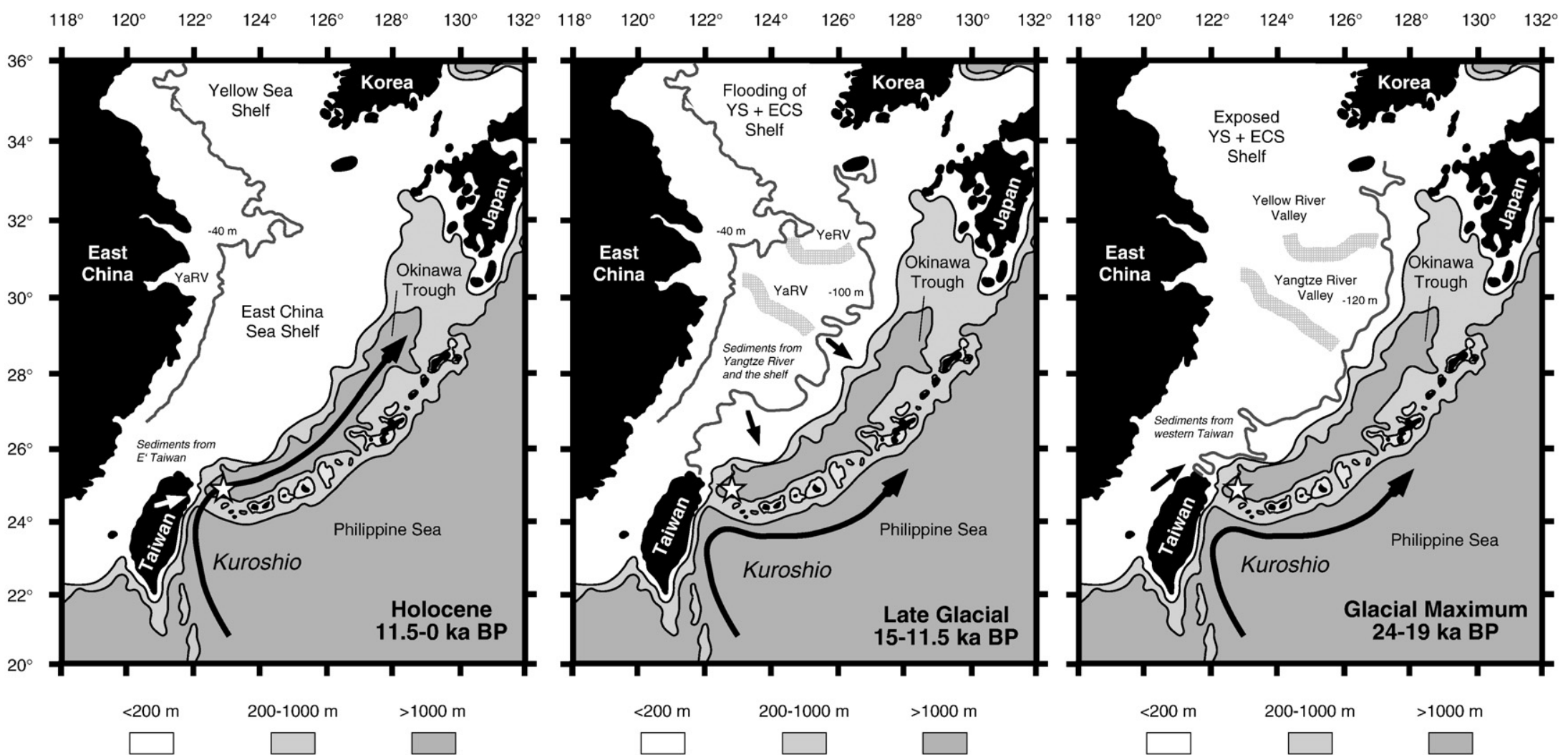

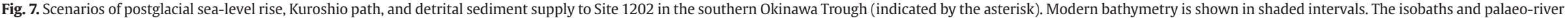

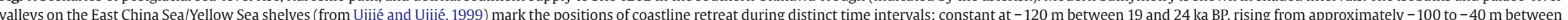
15.0 and $11.1 \mathrm{ka}$ BP, and rising from approximately - 40 to present position during the Holocene. Abbreviations: (YS) Yellow Sea, (ECS) East China Sea, (YeRV) Yellow River Valley (YaRV), Yangtze River Valley. 
Table 1

Clay-mineral assemblages in modern marine sediments of the East China continental margin and around Taiwan

\begin{tabular}{|c|c|c|c|c|c|c|c|c|}
\hline & $\begin{array}{l}\text { Smectite* } \\
(\%)\end{array}$ & $\begin{array}{l}\text { Illite } \\
(\%)\end{array}$ & $\begin{array}{l}\text { Kaolinite } \\
(\%)\end{array}$ & $\begin{array}{l}\text { Chlorite } \\
(\%)\end{array}$ & Ill/Sm ratio & Chl/Kao ratio & Samples \# & Reference \\
\hline Yellow Sea & $40.2 \pm 1.6$ & $39.4 \pm 1.8$ & $8.0 \pm 0.5$ & $11.9 \pm 0.6$ & $1.0 \pm 0.1$ & $1.5 \pm 0.1$ & 9 & Eisma et al. $(1995)^{\mathrm{a}}$ \\
\hline East China Sea Shelf & $37.5 \pm 6.6$ & $42.2 \pm 4.3$ & $6.8 \pm 0.6$ & $13.4 \pm 2.6$ & $1.2 \pm 0.4$ & $2.0 \pm 0.6$ & 10 & \\
\hline Yellow River Delta & 52.0 & 30.3 & 8.0 & 9.3 & 0.6 & 1.2 & 3 & \\
\hline Old Yellow Riv. Delta & 49.0 & 35.0 & 7.5 & 10.0 & 0.7 & 1.3 & 2 & \\
\hline Yangtze River Mouth & 35.0 & 42.0 & 10.0 & 13.0 & 1.2 & 1.3 & 3 & \\
\hline NW Taiwan Shelf & $19.8 \pm 8.2$ & $54.3 \pm 5.6$ & $7.2 \pm 1.1$ & $18.3 \pm 3.7$ & $3.4 \pm 1.7$ & $3.4 \pm 1.7$ & 24 & \\
\hline East China Sea Shelf & $5.8 \pm 1.4$ & $55.0 \pm 3.6$ & $13.7 \pm 1.7$ & $25.4 \pm 2.8$ & $10.0 \pm 3.4$ & $1.9 \pm 0.4$ & 6 & Aoki and Oinuma (1974) \\
\hline Okinawa Trough & $5.3 \pm 2.7$ & $69.0 \pm 5.5$ & $6.0 \pm 1.2$ & $19.7 \pm 6.0$ & $17.5 \pm 11.1$ & $3.3 \pm 0.8$ & 8 & \\
\hline Okinawa Trough & $3.4 \pm 2.2$ & $64.9 \pm 4.8$ & $9.6 \pm 1.8$ & $22.1 \pm 3.2$ & $28.0 \pm 16.9$ & $2.4 \pm 0.6$ & 15 & Lin and Chen $(1983)^{c}$ \\
\hline East China Sea Shelf & 8.0 & 60.5 & 7.5 & 23.9 & 7.6 & 3.2 & 14 & Chen $(1973)^{d}$ \\
\hline NW Taiwan Shelf & 5.0 & 64.0 & 8.0 & 23.0 & 13.0 & 2.9 & 13 & \\
\hline SW Taiwan Shelf & 5.9 & 64.3 & 5.3 & 24.4 & 10.9 & 4.6 & 13 & \\
\hline S Taiwan Shelf & 5.0 & 65.0 & 5.0 & 25.0 & 13.0 & 5.0 & 6 & \\
\hline E Taiwan Shelf & 6.4 & 61.9 & 5.0 & 26.6 & 9.7 & 5.3 & 5 & \\
\hline E Taiwan, abyssal & 9.0 & 62.0 & 5.0 & 24.0 & 6.9 & 4.8 & 4 & \\
\hline
\end{tabular}

* Smectite refers to expandable clay species (smectite group and mixed-layer clays).

Percentages are given with standard deviation (where possible). Note that the quantification methods are not consistent between the different authors.

a Clay-mineral quantification according to major XRD peak height intensities (17 $\AA, 10 \AA$, $7 \AA$ ) without weighting factors, Ill/Sm=10 $/ / 17 \AA$, Chl/Kao=3.54 $\mathrm{A} / 3.57 \AA \AA$ Peak intensities.

b Clay-mineral quantification is not explained in the publication.

c Clay-mineral quantification according to major XRD peak areas with weighting factors $17 \AA \times 1 / 10 \AA \times 4 / 7 \AA \times 2.5$, Ill $/ \mathrm{Sm}=10 \AA \AA / 7 \AA$, Chl/Kao=3.54 $/ 3.57 \AA$ Peak intensities.

d Clay-mineral quantification according to major XRD peak areas with weighting factors $17 \AA \times 1 / 10 \AA \times 4 / 7 \AA \times 2.5$, Ill/Sm $=10 \AA / 17 \AA$, Chl/Kao=3.54 $\AA / 3.57 \AA$ Peak intensities.

Site 1202 section can be assumed, when considering that the time intervals which were characterized by sediment supply from the relatively nearby sources of Taiwan reveal increased sand concentrations, as seen for the old section and the Holocene section, whereas sand particles from East China cannot reach the Okinawa Trough, as seen in the almost sand-free intervals between 19.5 and $11.2 \mathrm{ka}$. Looking at the fine fraction, the grain-size composition of the silt and clay fraction is constant in the hemipelagic muds older than $11.2 \mathrm{kyr}$, generally showing high clay amounts and moderate silt concentrations with variable sand concentrations (Fig. 3). A coarsening of the fine fraction towards increased silt concentrations at the expense of clay is evident for the Holocene. This marked change in the grain-size composition of the hemipelagic muds is best displayed by stepwise increases in the amount of sortable silt (grain-size fraction between 63 and $10 \mu \mathrm{m}$ ) and the mean grain-size of the silt and clay fraction. Both parameters are normally used to infer changes in palaeo current strengths of ocean bottom currents (Ledbetter, 1984; McCave et al., 1995; Kuhn and Diekmann, 2002).

At Site 1202, the grain-size signal has to be regarded as an indicator of the vigour of the complex regional current system, which is basically determined by the Kuroshio surface current system (see Section 2). According to Hsu et al. (1998), our basic interpretation is that an active and strong Kuroshio is needed for the transportation of suspended coarse silt over the southern Okinawa Trough. Today, the mean geostrophic current speed of the Kuroshio off the northeastern Taiwan area fluctuates between 36 and 202 cm/s (Andres et al., 2008). This speed is sufficient to carry and erode coarse silt and fine sand particles efficiently, according to the classical conception of the empirical Hjulstrøm Curves (e.g. Kennett, 1982). The associated Kuroshio eddy cells north of Taiwan, promote natural sediment trapping and sucking to the deeper water, feeding the slope countercurrent below 550 m water depths (Chuang et al., 1993; Hsu et al., 1998). The southern Mien-Hua Canyon is situated below the Kuroshio eddies and provides the conduit for hemipelagic sediment transfer to the deep. Sedimentological and sediment-acoustic data show that the canyon today is not affected by gravitational sedimentary processes that shaped the canyon in the past (Hong and Chen, 2000).

The main jet of the counter current is located at $600-800 \mathrm{~m}$ water depth with a current speed of up to $25 \mathrm{~cm} / \mathrm{s}$ (Chuang et al., 1993; Nakamura et al., 2008). It can be traced down to the lower continental slope at about $1450 \mathrm{~m}$ water depth, where it appears at an average current speed of $3 \mathrm{~cm} / \mathrm{s}$ and finally is blocked by the I-Lan Ridge (Chung and Hung, 2000). From this circulation pattern it becomes clear, why Site 1202 receives such tremendous amounts of clayey-silty sediments, as it lies at the end of the complex local Kuroshio current structure on the northern slope of the I-Lan Ridge, where sediment transport energy gets lost and particulate loads settle out. In conclusion, the identification of Kuroshio-related sedimentary signals at Site 1202 is possible when: (1) fluvial sediment is supplied from northeastern Taiwan, (2) transportation across the I-Lan Ridge is realized, (3) the upwelling domes are active, and (4) the deep counter current is present.

In the Site 1202 record, these preconditions can be substantiated for the Holocene by provenance signals from eastern Taiwan, most likely from the Lan-Yang River. If the Kuroshio is not active or deflected outside the Okinawa Trough, fluvial suspensions from there, if present, would not reach the Okinawa Trough. The presence of associated eddies and counter currents are needed to have the silty clayey hemipelagic sediments carried to the deep trough. Coarser fluvial sand might reach the trough directly through episodic subaquatic plumes shed across the I-Lan Ridge. This process possibly is documented by the dispersed turbiditic sand stringers in the Site 1202 record that are, however, not studied here.

\subsection{Detrital sediment supply and its relation to regional palaeoenvironmental changes}

The interpretation of changes in the modes of detrital sediment input at Site 1202 has to invoke two main factors that influence the depositional environment. They comprise pronounced sea-level fluctuations during the last $28 \mathrm{kyr}$ that controlled the position of shore lines in the shelf areas (e.g. Hanebuth et al., 2000; Lambeck et al., 2002; Liu et al., 2004) and changes in the regional monsoon system that controlled the intensity of fluvial runoff (e.g. Morley and Heusser, 1997; Wang et al., 1999). In addition to sea-level effects, it has been proposed that tectonic movements influenced the exposure of land masses. A potential land bridge between Taiwan and the Ryuyku Island Arc across the I-Lan Ridge has been postulated to have existed prior to $10 \mathrm{ka}$ before it subsided in the Holocene (Ujiié and Ujiié, 1999). However, we agree with Jian et al. (2000) that, according to the present sill depth, vertical movements of 
about $800 \mathrm{~m}$ in combination with sea-level rise are hard to imagine to have taken place in such a short time interval like the Holocene. Next, we consider environmental changes and their impacts on the detrital sediment supply at Site 1202 in the chronological frame of distinct time intervals that delineate critical thresholds in the environmental history (Figs. 6 and 7).

\subsubsection{Time interval $28-19.5 \mathrm{ka} \mathrm{BP}$}

During this time period of the last glacial climate stage, provenance proxies indicate a high detrital sediment supply of clay-rich material from northwestern Taiwan. Low amounts of sortable silt and the absence of terrigenous sediments from eastern Taiwan (Lan-Yang River) indicate an insignificant influence of the Kuroshio current system on sedimentation in the southern Okinawa Trough, if present at all. This time interval was characterized by a global sea-level low stand at $-120 \mathrm{~m}$ below the present level, which started to exist at about 30 ka BP (Lambeck et al., 2002). The foregoing regression is documented by prograding delta sequences of the Yangtze River on the East China Sea shelf, while the sea-level low stand led to the emergence of an exposed East China Sea shelf (Saito et al., 1998). Palaeoclimate reconstructions point to reduced summer monsoon activity in the southeast Asian region (Wang et al., 1999, 2005) and cooler and dryer conditions than present in Taiwan (Liew et al., 2006).

The sedimentary pattern in the southern Okinawa Trough is consistent with a low sea-level scenario. The inferred absence of the Kuroshio over the Okinawa Trough supports the assumption of a Kuroshio flow east of the Ryukyu Island Arc (Ujiié et al, 1991; Ahagon et al., 1993). The sea-level controlled deflection of the Kuroshio is also documented by the dominance of coastal East China Sea waters over the Okinawa Trough, inferred from micropalaeontological indicators (Xu and Oda, 1999). Although small gaps might have existed in the Ryukyu Island arc, the wide oceanographic isolation of the Okinawa Trough from the open Pacific Ocean favoured the supply of detrital materials from northwestern Taiwan. Today, sediments from fluvial sources of northwestern Taiwan are carried through the Chilung Sea Valley (Fig. 1) by northeastward currents originating in the Taiwan Strait (Hong and Chen, 2000). The relative contribution from this source to modern sediment fluxes in the Okinawa Trough is low, but apparently was strongly increased between 28 and $19.5 \mathrm{ka}$ BP. During the last glacial sea-level low stand, the Chilung Sea Valley, which roughly runs parallel to the northern Taiwan coast, represented the lower reach of the Tanshui River (Boggs et al., 1979). Probably this depression was the main conduit for sediment dispersal from northwestern Taiwan to the southern Okinawa Trough, as also documented by sub-bottom sediment-acoustic features (Hong and Chen, 2000).

\subsubsection{Time interval $19.5-11.2 \mathrm{ka}$}

The beginning of this time interval in the younger part of the last glacial maximum climate stage (24-18 ka BP) is marked by an abrupt shift in dominant sediment provenance from northwestern Taiwan in favour of materials derived from East China. In particular, this source was strongly active during the late glacial period after $15 \mathrm{ka} \mathrm{BP}$, reflected by maximum documented sedimentation rates in the investigated Site 1202 section. As in the preceding time interval, low amounts of sortable silt and provenance data indicate an insignificant influence of the Kuroshio current system on detrital sediment fluxes in the southern Okinawa Trough. During this time interval, prolonged eustatic sea-level rise took place in distinct pulses in conjunction with global deglaciation processes (Hanebuth et al., 2000; Lambeck et al., 2002; Liu et al., 2004). The termination of the glacial maximum and ongoing establishment of postglacial climate conditions is also documented by an growing intensity of summer monsoon in eastern Asia and adjacent oceans in response to a continuous increase in lowlatitude insolation between ca. 20 and 11 ka BP (Morley and Heusser, 1997; Wang et al., 1999, 2005).
Both factors, sea-level rise and climate amelioration, may have triggered a change in detrital sediment provenance at Site 1202. According to the observed provenance signal from East China, both factors have to be considered in how far they have affected changes in the fluvial sediment supply of the Yangtze River or the reworking of older sediment of same origin on the outer East China Sea shelf and slope. In this regard, sea-level controlled the extent of emerged shelf areas, the degree of sediment reworking during marine transgression, and the proximity of the Yangtze River mouth to the Okinawa Trough, while climate humidity basically controlled the amount of river runoff. Geological witness of sediment reworking and erosion is given by winnowed relic sediments at the shelf edge (Hong and Chen, 2000) and the presence of a marked hiatus and unconformity on the shelf, spanning approximately the time between 25 and $11 \mathrm{ka}$ BP (Saito et al., 1998).

The change in sediment sources at 19.5 ka BP nearly is consistent with an initial sea-level rise by about $15 \mathrm{~m}$ (Clark et al., 2004). During the last glacial maximum the Yangtze mouth was situated at the shelf edge close to the central Okinawa Trough (Ujiie et al., 2001). The subsequent small-scale sea-level rise only slightly shifted the position of the river mouth (Fig. 7). The effect of sediment redeposition cannot be ruled out from the Site 1202 record, although low sedimentation rates do not favour this interpretation. Findings from the central and northern Okinawa Trough, however, provide a better picture of environmental change after the last glacial maximum. There, close to the palaeo river mouths of the Yangtze and Yellow Rivers, sedimentation rates already increased since about 19 ka BP (Xu and Oda, 1999; Xiang et al., 2007) and were linked with fresh-water signals, inferred from faunal evidence (Xu and Oda, 1999) and organic matter composition (Ujiie et al., 2001). Increased fluvial runoff in response to enhanced summer monsoon apparently increased the overall supply of East China sediments to the Okinawa Trough as far as the southern Okinawa Trough.

At Site 1202, a dramatic increase in sedimentation rates appeared at around $15 \mathrm{ka} \mathrm{BP}$, without significant changes in prevailing sediment sources. The exact datum, however, might be variable in respect to the applied relatively low-resolution age model. The timing of increased sedimentation rates approximates the beginning of the BøllingAllerød warming stage (14.7 ka BP) and a related $25-\mathrm{m}$ pulse in sealevel rise between 14.3 and 14.1 ka BP (Liu et al., 2004). During that time East Asian climate became warmer an moister than before (Wang et al., 2005; Yancheva et al., 2007; Wang et al., 2008), as also recorded in palaeoclimatic land records of Taiwan (Wei et al., 2003; Liew et al., 2006) and palaeo sea-surface temperature reconstructions in the Okinawa Trough (Li et al., 2001; Xiang et al., 2007). The high degree of humidity and fluvial runoff is reflected in faunal and geochemical fresh-water signals in both the distant Japan Sea (Lee, 2007) and in the central Okinawa Trough (Xu and Oda, 1999), while organic matter composition in the Okinawa Trough suggests an decreasing influence of terrestrial-derived particulate fluvial sediment loads that might be related to the retreat of the Yangtze River Mouth (Ujiie et al., 2001). In our data, we still see the Yangtze/East China signal. However, we suggest that it is basically related to sediment reworking in the course of postglacial shelf flooding, because of the extremely high sedimentation rates.

\subsubsection{Time interval $11.2 \mathrm{ka}$ to present}

The lower boundary of this stage is consistent with the beginning of the Holocene. It is marked by another change in sediment provenance that appears across a transition interval between 11.5 and $9.0 \mathrm{ka} \mathrm{BP}$ and implies a change from dominant detrital sediment sources from East China towards a prevailing sediment supply from nearby eastern Taiwan. The transition is marked by grain-size coarsening that appeared in two steps. The change in sediment provenance and grain-size documents the invigoration of ocean circulation in the southern Okinawa Trough and the reentrance of the 
Kuroshio that occurred in two pulses at 11.2 and 9.5 ka BP respectively. Through the remaining part of the Holocene, the depositional conditions apparently remained stable. The 11.2-ka datum marks the beginning of early Holocene warming after the Younger Dryas cold event (11.55-12.7 ka BP) that cannot be recognized in terms of detrital fluxes at Site 1202. The end of the Younger Dryas was associated with a sudden sea-level rise from about -60 to $-45 \mathrm{~m}$ below the present level, followed by another rapid 15-m rise between 9.5 and $9.2 \mathrm{ka}$ BP that shifted the Yangtze mouth close to its present position at $-15 \mathrm{~m}$ water depth (Liu et al., 2004). The retreat of the coast line and extended shelf flooding is also indicated by the formation of widespread sand ridges on the East China Sea shelf after 11 to $8 \mathrm{ka}$ BP (Saito et al., 1998). In the early Holocene, climate amelioration reached an optimum with maximum summer monsoon influence, causing overall high temperatures and humidity in eastern Asia and adjacent oceans, as recorded in ice-core records from the Tibetan Plateau (Thompson et al., 1997), east Asian lake records (e.g. Yancheva et al., 2007), Chinese cave records (Wang et al., 2008), and marine records from the Chinese seas (Wang et al., 1999, 2005). The climate optimum is also recorded in the lower reaches of the Yangtze River (Yi and Saito, 2004), in land records from Taiwan (Liew et al., 2006), and in the marine temperature records of the central Okinawa Trough (Xu and Oda, 1999; Xiang et al., 2007), and at Site 1202 (Zhao et al., 2005).

From our data, however, it appears that the influence of Yangtze River discharge and monsoon dynamics on detrital sediment fluxes in the southern Okinawa Trough eased, after sea-level rise had reached a critical threshold that permitted the reentrance of the Kuroshio into the Okinawa Trough, promoting strong sediment supply from eastern Taiwan. The establishment of the modern current system in two pulses indeed is consistent with the two prominent episodes of rapid sea-level rise in the earliest Holocene.

The onset of Kuroshio influence between 11.2 and 9.5 ka underlines the outcomes from other palaeoceanographic investigations of Kuroshio dynamics. Thus, our interpretation of the intimate relation between Kuroshio surface circulation and its connection to deeper counter currents is supported by the inference of increased bottom-water ventilation after $10 \mathrm{ka} B P$, indicated by geochemical data and sedimentmagnetic properties (Kao et al., 2005). In the central Okinawa Trough, the Kuroshio reentrance was connected with a deepening of the thermocline (Xiang et al., 2007). In the northern Okinawa Trough, a diminished influence of East China Sea coastal waters in favour of open marine conditions was found, which can be related to a substantial Kuroshio influence since $10.5 \mathrm{ka}$ (Xu and Oda, 1999).

Other palaeoceanographic studies, however, yielded controverse results. Thus, Li et al. (2001) found a gradual increase of Kuroshio influence since 16 ka punctuated by short-term episodes of Kuroshio weakening, while Ujiié et al. (2003) inferred Kuroshio strengthening since $13.0 \mathrm{ka}$ and its intensification after $10.0 \mathrm{ka}$, and a repeated weakening in the late Holocene between 4.5 and $3.0 \mathrm{ka}$. Other authors suggest a later onset of Kuroshio influence in the Okinawa Trough that started around 9.1-9.0 ka (Li et al., 1997; Su and Wei, 2005) or rather not earlier than $7.3 \mathrm{ka}$ (Jian et al., 2000). Outside the Okinawa Trough, marine records from offshore central Japan for instance clearly point to stepwise invigorations of Kuroshio activity that took place at $13.0 \mathrm{ka}, 10.5 \mathrm{ka}$, and $7.0 \mathrm{ka}$, respectively (Chinzei et al., 1987; Sawada and Handa, 1998). Since the latter studies were mainly concerned with reconstructions of palaeo sea-surface temperatures, these findings basically provide insights into the temporal development of westernboundary heat transport in the northwestern Pacific realm. Even during the maximum sea-level low stand, it can be expected from the present bathymetry that gaps existed between the open Pacific and the Okinawa Trough that permitted the exchange of surface waters. In contrast, our data basically reflect the postglacial establishment of the high-energetic modern Kuroshio current system in the Okinawa Trough, implying the complex relationship between surface currents, upwelling cells, and the vertical connection to deep counter currents.

\subsection{Global implications}

Our study on detrital sediment fluxes in the Okinawa Trough has shown that the regional marine environmental changes off northeastern Taiwan were basically influenced by the stepwise shifts of postglacial sea-level rise and to a lesser degree by progressive climate amelioration since the start of the Bølling-Allerød some $14.7 \mathrm{kyr}$ ago (Fig. 6). Deglacial cooling episodes, such as Heinrich Event 1 (17.714.7 ka BP) and the Younger Dryas event (12.7-11.6 ka BP), and late Holocene cooling apparently had no strong impact on the environmental changes, ruling out significant climatic teleconnections to the Northern Atlantic. The existence of such teleconnections nonetheless has been exemplified by stalagmite records in Chinese caves (Wang et al., 2008) and marine records of the Chinese seas (Wang et al., 1999, 2005; Steinke et al.,2008) (Fig. 6). The lack of these palaeoclimatic information in the Site 1202 record might be caused by the overwhelming signal of sea-level change on Kuroshio dynamics in the southern Okinawa Trough. Another possibility is that the Site 1202 record reflects the palaeoclimatic signals that were propagated northward from the western Pacific warm pool. Latest findings from cave stalagmites in northern Borneo (Fig. 6) actually demonstrate that deglacial climate warming in the western equatorial Pacific realm developed quite steadily since about $15.5 \mathrm{ka}$ BP in response to insolation change (Partin et al., 2007). Further palaeoceanographic studies from outside the Okinawa Trough may help to clarify the question of potential climate teleconnections from the equatorial Pacific Ocean towards the higher latitudes of the northern Pacific Ocean.

\section{Conclusions}

The late Quaternary detrital sediment record of Site 1202 from the southern Okinawa Trough provides insights into the variability of terrigenous sediment provenance and dispersal related to regional palaeoenvironmental changes during the last 28 kyr. Detrital sediments mainly originate from Taiwan and East China, supplied by fluvial discharge and distributed by regional ocean circulation. Variations in sea-level exerted the strongest control on changes in sediment provenance and Kuroshio dynamics, temporarily affected by changes in monsoon climate (Figs. 6 and 7):

- During the last glacial period, low sea-level exposed the East China Sea shelf and isolated the Okinawa Trough from direct Kuroshio inflow until to $11.2 \mathrm{ka}$ BP.

- Between 28 and 19.5 ka BP, local fluvial sediments from northwestern Taiwan were shed through the Chilung Sea Valley into the southern Okinawa Trough.

- A change in provenance during the last glacial maximum at $19.5 \mathrm{ka} \mathrm{BP}$, reflects increased fluvial runoff from the Yangtze River and sedimentary reworking of the East China Sea shelf. It was caused by the combined effects of increased humidity through enhanced summer monsoon and prolonged sea-level rise. Between 15.1 and $11.1 \mathrm{ka}$ BP, extremely high sedimentation rates were related to Bøllering-Allerød climate amelioration and accelerated sea-level rise.

- Between 11.2 and 9.0 ka BP, prevailing sediment provenance switched to northeastern Taiwan sources, accompanied by two pulses in ocean current strengthening (11.2 and 9.5 ka BP) in response to two episodes of rapid sea-level rise, respectively. By that time, the East China coastline already was close to its present position.

- Since 9.0 ka BP, the depositional environment of the Holocene was controlled by the presence and activity of the complex Kuroshio current system that carries the sediment loads of the Lan-Yang River (northeastern Taiwan) across the I-Lan Ridge to the southern Okinawa Trough.

- Postglacial episodes of climate cooling, such as Heinrich Event 1 and the Younger Dryas event, apparently did not affect the marine sedimentary environment of the southern Okinawa Trough, and rule out climate teleconnections from the North Atlantic, otherwise seen 
in many marine and terrestrial palaeo monsoon records of southeastern Asia. The progressive postglacial environmental change in the southern Okinawa Trough rather shows affinities to deglacial climate change in the western Pacific warm pool.

\section{Acknowledgements}

This research used samples and data provided by the Ocean Drilling Program, which is sponsored by the U.S. National Science Foundation and participating countries under management of the Joint Oceanographic Institutions. Funding of this study was provided by the Deutsche Forschungsgemeinschaft through grant He 1671/11-1 ("Palaeoclimate Philippine Sea“). We thank the organizers of the Ocean Drilling Program for inviting B.D. as ship-board participant of Leg 195 and we appreciate the kind assistance of the 'JOIDES Resolution' ship crew and scientists. The manuscript benefited from the comments and constructive suggestions of Gert De Lange, Lionel Carter, Zhifei Liu, and Koshi Yamamoto.

\section{References}

Ahagon, N., Tanaka, Y., Ujiié, H., 1993. Florisphaera profunda, a possible nanoplankton indicator of late Quaternary changes in sea-water turbidity at the northwestern margin of the Pacific. Mar. Micropaleontol. 22, 255-273.

Andres, M., Wimbush, M., Park, J.-H., Chang, K.-I., Lim, B.-H., Watts, D.R., Ichikawa, H., Teague, W.J., 2008. Observations of Kuroshio flow variations in the East China Sea. J. Geophys. Res. 113, C05013. doi:10.1029/2007JC004200.

Aoki, S., Oinuma, K., 1974. Clay mineral compositions in recent marine sediments around Nansei-Syoto Islands, south of Kyusyu, Japan. J. Geol. Soc. Jpn. 80, 57-63.

Biscaye, P.E., 1965. Mineralogy and sedimentation of recent deep-sea clay in the Atlantic Ocean and adjacent seas and oceans. Bull. Geol. Soc. Am. 76, 803-832.

Boggs, J.S., Wang, W.C., Lewis, F.S., Chen, J.C., 1979. Sediment properties and water characteristics of the Taiwan shelf and slope. Acta Oceanographica Taiwanica 10,10-49.

Chen, P.-Y., 1973. Clay minerals distribution in the sea-bottom sediments neighbouring Taiwan Island and northern South China Sea. Acta Oceanogr. Taiwan 3, 25-64.

Chen, P.-Y., 1978. Minerals in bottom sediments of the South China Sea. Bull. Geol. Soc. Am. 89, 211-222.

Chinzei, K., Fujioka, K., Kitazato, H., Koizumi, I., Oba, T., Oda, M., Okada, H., Sakai, T., Tanimura, Y., 1987. Postglacial environmental change of the Pacific Ocean off the coasts of central Japan. Mar. Micropaleontol. 11, 273-291.

Chuang, W.S., Li, H.W., Tang, T.Y., Wu, C.K., 1993. Observations of the counter current on the inshore side of the Kuroshio northeast of Taiwan. J. Oceanogr. 49, 581-592.

Chung, Y.C., Hung, G.W., 2000. Particulate fluxes and transports on the slope between the southern East China Sea and the South Okinawa Trough. Cont. Shelf Res. 20, 571-597.

Clark, P.U., McCabe, A.M., Mix, A.C., Weaver, A.J., 2004. Rapid rise of sea level 19,000 years ago and its global implications. Science 304, 1141-1144.

Dorsey, R.J., Buchovecky, E.C., Lundberg, N., 1988. Clay mineralogy of Pliocene-Pleistocene mudstones, eastern Taiwan: combined effects of burial diagenesis and provenance unroofing. Geology 16, 944-947.

Ehrmann, W.U., Melles, M., Kuhn, G., Grobe, H., 1992. Significance of clay mineral assemblages in the Antarctic Ocean. Mar. Geol. 107, 249-273.

Eisma, D., Ji, Z., Chen, S., Chen, M., van der Gaast, S.J., 1995. Clay mineral composition of recent sediments along the China coast in the Yellow Sea and the East China Sea. NIOZ-Rapport 1995-4. Nederlands Instituut voor Onderzoek der Zee. 13 pp.

Hanebuth, T., Stattegger, K., Grootes, P.M., 2000. Rapid flooding of the Sunda Shelf: a late glacial sea-level record. Nature 288, 1033-1035.

Hong, E., Chen, I.S., 2000. Echo characters and sedimentary processes along a rifting continental margin, northeast of Taiwan. Cont. Shelf Res. 20, 599-617.

Hsin, Y.-C., Wu, C.-R., Shaw, P.-T., 2008. Spatial and temporal variations of the Kuroshio east of Taiwan, 1982-2005: a numerical study. J. Geophys. Res. 113, C04002. doi:10.1029/2007JC004485

Hsu, S.-C., Lin, F.-J., Jeng, W.-L., Tang, T.Y., 1998. The effect of a cyclonic eddy on the distribution of lithogenic particles in the southern East China Sea. J. Mar. Res. 56, 813-832.

Hsu, S.C., Lin, F.J., Jeng, W.L., Chung, Y.C., Shaw, L.M., Hung, K.W., 2004. Observed sediment fluxes in the southwesternmost Okinawa Trough enhanced by episodic events: flood runoff from Taiwan rivers and large earthquakes. Deep-Sea Res. I 51, 979-997.

Huang, C.-Y., Chiu, Y.-L., Zhao, M., 2005. Core description and preliminary sedimentological study of Site 1202D, Leg 195, in southern Okinawa Trough. Terrestr. Atmos. Oceanic Sci. 16, 19-44

Hung, J.J., Lin, C.S., Hung, G.W., Chung, Y.C., 1999. Lateral transport of lithogenic particles from the continental margin of the southern East China Sea. Estuar. Coast. Shelf Sci. 49, 483-499.

Jansen, J.H.F., Van der Gaast, S.J., Kloster, B., Vaars, A.J., 1998. CORTEX, a shipboard XRF scanner for element analyses in split sediment cores. Mar. Geol. 151, 143-153.

Jeng, W.-L., Lin, S., Kao, S.-J., 2003. Distribution of terrigenous lipids in marine sediments off northeastern Taiwan. Deep-Sea Res. II 50, 1179-1201.

Jian, Z., Wang, P., Saito, Y., Wang, J., Pflaumann, U., Oba, T., Cheng, X., 2000. Holocene variability of the Kuroshio Current in the Okinawa Trough, northwestern Pacific Ocean. Earth Planet. Sci. Lett. 184, 305-319.
Kao, S.J., Lin, F.J., Liu, K.K., 2003. Organic carbon and nitrogen contents and their isotopic compositions in surficial sediments from the East China Sea shelf and the southern Okinawa Trough. Deep-Sea Res. II 50, 1203-1217.

Kao, S.J., Horng, C.S., Hsu, S.C., Wei, K.-Y., Chen, J.C., Lin, Y.S., 2005. Enhanced deepwater circulation and shift of sedimentary organic matter oxidation pathway in the Okinawa Trough since the Holocene. Geophys. Res. Lett. 32, L15609. doi:10.1029/ 2005GL023139.

Kao, S.J., Dai, M.H., Wei, K.-Y., Blair, N.E., Lyons, W.B., 2008. Enhanced supply of fossil organic carbon to the Okinawa Trough since the last deglaciation. Paleoceanogr. 23 1-10, PA2207. doi:10.1029/2007PA001440.

Kennett, J.P., 1982. Marine Geology. Prentice-Hall, Englewood Cliffs. 813 pp.

Kuhn, G., Diekmann, B., 2002. Late Quaternary variability of ocean circulation in the southeastern South Atlantic inferred from the terrigenous sediment record of a drift deposit in the southern Cape Basin (ODP Site 1089). Palaeogeogr. Palaeoclimatol. Palaeoecol. 182, 287-303.

Lambeck, K., Yokoyama, Y., Purcell, T., 2002. Into and out of the Last Glacial Maximum: sea-level change during Oxygen Isotope Stages 3 and 2. Quat. Sci. Rev. 21, 343-360.

Ledbetter, M.T., 1984. Bottom-current speed in the Vema Channel recorded by particle size of sediment fine-fraction. Mar. Geol. 58, 137-149.

Lee, K.E., 2007. Surface water changes recorded in Late Quaternary marine sediments of the Ulleung Basin, East Sea (Japan Sea). Palaeogeogr. Palaeoclimatol. Palaeoecol. 247, 18-31.

Lee, H.-J., Chao, S.-Y., 2003. A climatological description of circulation in and around the East China Sea. Deep-Sea Res. II 50, 1065-1084.

Li, B., Jian, Z., Wang, P., 1997. Pulleniatina obliquiloculata as a paleoceanographic indicator in the southern Okinawa Trough during the last 20,000 years. Mar. Micropaleontol. 32, 59-69.

Li, T., Liu, Z., Hall, M.A., Berne, S., Saito, Y., Cang, S., Cheng, Z., 2001. Heinrich event imprints in the Okinawa Trough: evidence from oxygen isotope and planktonic foraminifera. Palaeogeogr. Palaeoclimatol. Palaeoecol. 176, 133-146.

Li, T., Xiang, R., Sun, R., Cao, Q., 2005. Benthic foraminifera and bottom water evolution in the middle-southern Okinawa Trough during the last $18 \mathrm{ka}$. Sci. China, Ser B Earth Sci. 48, 805-814.

Liew, P.-M., Huang, S.-Y., Kuo, C.-M., 2006. Pollen stratigraphy, vegetation and environment of the last glacial and Holocene-a record from Toushe Basin, central Taiwan. Quat. Internat. 147, 16-33.

Lin, F.J., Chen, J.C., 1983. Textural and mineralogical studies of sediments from the southern Okinawa Trough. Acta Oceanogr. Taiwan 14, 26-41.

Liu, K.-K., Peng, T.-H., Shaw, P.-T., Shiah, F.-K., 2003. Circulation and biogeochemical processes in the East China Sea and the vicinity of Taiwan: an overview and a brief synthesis. Deep-Sea Res. II 50, 1055-1064.

Liu, J.P., Milliman, J.D., Gao, S., Cheng, P., 2004. Holocene development of the Yellow River's subaqueous delta, North Yellow Sea. Mar. Geol. 209, 45-67.

Liu, J.P., Xu, K.H., Li, A.C., Milliman, J.D., Velozzi, D.M., Xiao, S.B., Yang, Z.S., 2007. Flux and fate of Yangtze River sediment delivered to the East China Sea. Geomorphol. 85, 208-224.

McCave, I.N., Manighetti, B., Robinson, S.G., 1995. Sortable silt and fine sediment size/ composition slicing: parameters for palaeocurrent speed and palaeoceanography. Paleoceanogr. 10, 593-610.

Morley, J.J., Heusser, L.E., 1997. Role of orbital forcing in east Asian monsoon climates during the last 350 kyr: evidence from terrestrial and marine climate proxies from core RC14-99. Paleoceanogr. 12, 483-493.

Nakamura, H., Nishina, A., Ichikawa, H., Nonaka, M., Sasaki, H., 2008. Deep countercurrent beneath the Kuroshio in the Okinawa Trough. J. Geophys. Res. 113, C06030. doi:10.1029/2007JC004574.

Oguri, K., Matsumoto, E., Yanada, M., Saito, Y., Iseki, K., 2003. Sediment accumulation rates and budgets of depositing particles of the East China Sea. Deep-Sea Res. II 50 513-528.

Partin, J.W., Cobb, K.M., Adkins, J.F., Clark, B., Fernandez, D.P., 2007. Millennial-scale trends in west Pacific warm pool hydrology since the Last Glacial Maximum. Nature 449, 452-455.

Petschick, R., Kuhn, G., Gingele, F.X., 1996. Clay mineral distribution in surface sediments of the South Atlantic: sources, transport, and relation to oceanography. Mar. Geol. 130, 203-229.

Rea, D.K., 1990. Aspects of atmospheric circulation: the Late Pleistocene (0-950,000 yr) record of eolian deposition in the Pacific Ocean. Palaeogeogr. Palaeoclimatol. Palaeoecol. 78, 217-227.

Richter, C., Venut, A., Verosub, K.L., Wei, K.Y., 2006. Variations of the geomagnetic field during the Holocene: Relative paleointensity and inclination record from the West Pacific (ODP Hole 1202B). Phys. Earth Planet. Interiors 156, 179-193.

Röhl, U., Abrams, L.J., 2000. High-resolution, downhole and non-destructive core measurements from Sites 999 and 1001 in the Caribbean Sea: applications to the Late Paleocene Thermal Maximum. Proc. ODP, Sci. Res. 165, 191-203.

Saito, Y., Katayama, H., Ikehara, K., Kato, Y., Matsumoto, E., Oguri, K., Oda, M., Yumoto M., 1998. Transgressive highstand system tracts and post-glacial transgression, the East China Sea. Sediment. Geol. 122, 217-232.

Sawada, K., Handa, N., 1998. Variability of the path of the Kuroshio ocean current over the past 25,000 years. Nature 392, 592-595.

Shipboard Scientific Party, 2002. In: Salisbury, M.H., Shinohara, M., Richter, C., et al. (Eds.), Site 1202. Proc. ODP, Init. Repts., p. 195. [CD-ROM]. Available from: Ocean Drilling Program, Texas A\&M University, College Station TX 77845-9547, USA.

Steinke, S., Kienast, M., Groeneveld, J., Lin, L.-C., Chen, M.-T., Rendle-Bühring, R., 2008 Proxy dependence of the temporal pattern of deglacial warming in the tropical South China Sea: toward resolving seasonality. Quat. Sci. Rev. 688-700.

Su, X., Wei, K.-Y., 2005. Calcareous nannofossils and variation of the Kuroshio Current in the Okinawa Trough during the last 13,000 years. Terrestr. Atmos. Oceanic Sci. 16 , 95-111. 
Sun, Y., Oppo, D.W., Xiang, R., Liu, W., Gao, S., 2005. Last deglaciation in the Okinawa Trough: subtropical northwest Pacific link to Northern Hemisphere and tropical climate. Paleoceanogr. 20, PA4005. doi:10.1029/2004PA001061.

Thompson, L.G., Yao, T., Davis, M.E., Henderson, K.A., Mosley-Thompson, E., Lin, P.-N. Beer, J., Synal, H.-A., Cole-Dai, J., Bolzan, J.F., 1997. Tropical climate instability: the last glacial cycle from a Qinghai-Tibetan ice core. Science 276, 1821-1825.

Ujiié, H., Ujiié, Y., 1999. Late Quaternary course changes of the Kuroshio Current in the Ryukyu Arc region, northwestern Pacific Ocean. Mar. Micropaleontol. 37, 23-40.

Ujiié, H., Tanaka, Y., Ono, T., 1991. Late Quaternary paleoceanographic record from the middle Ryukyu Trench slope, northwest Pacific. Mar. Micropaleontol. 18, 115-128.

Ujiié, H., Makamura, T., Miyamoto, Y., Park, J.O., Hyun, S., Oyakawa, T., 1997. Holocen turbidite cores from the southern Ryukyu Trench slope: suggestions of periodic earthquakes. J. Geol. Soc. Jpn. 103, 590-603.

Ujiié, H., Hatakeyama, Y., Gu, X.X., Yamamoto, S., Ishiwatari, R., Maeda, L., 2001. Upward decrease of organic $\mathrm{C} / \mathrm{N}$ ratios in the Okinawa Trough cores: proxy for tracing the post-glacial retreat of the continental shore line. Palaeogeogr. Palaeoclimatol. Palaeoecol. 165, 129-140.

Ujiié, Y., Ujiié, H., Taira, A., Nakamura, T., Oguri, K., 2003. Spatial and temporal variability of surface water in the Kuroshio source region, Pacific Ocean, over the past 21,000 years: evidence from planktonic foraminfera. Mar. Micropaleontol. 49, 335-364.

Wang, L., Sarnthein, M., Erlenkeuser, H., Grimalt, J., Grootes, P., Heilig, S., Ivanova, E., Kienast, M., Pelejero, C., Pflaumann, U., 1999. East Asian monsoon climate during the Late Pleistocene: high-resolution sediment records from the South China Sea. Mar. Geol. 156, 245-284.

Wang, P., Clemens, S.C., Beaufort, L., Braconnot, P., Ganssen, G., Jian, Z., Kershaw, P. Sarnthein, M., 2005. Evolution and variability of the Asian monsoon system: state of the art and outstanding issues. Quat. Sci. Rev. 24, 595-629.

Wang, Y., Cheng, H., Edwards, R.L., Kong, X., Shao, X., Chen, S., Wu, J., Jiang, X., Wang, X., An, Z., 2008. Millennial- and orbital-scale changes in the East Asian monsoon over the past 224,000 years. Nature 451, 1090-1093.

Wei, K.-Y., 2006. Leg 195 synthesis: Site 1202-late Quaternary sedimentation and paleoceanography in the southern Okinawa Trough. In: Shinohara, M., Salisbury,
M.H., Richter, C. (Eds.). Proc. ODP, Sci. Res. 195,1-31 [Online: Available from http:// www-odp.tamu.edu/publications/195_SR/Volume/Synth/Synth3.pdf].

Wei, K.-Y., Chen, Y.-G., Lai, W.-S., Chen, L.-C., Fei, L.-Y., 2003. Climate change as the dominant control of the last glacial-Holocene $\partial^{13} \mathrm{C}$ variations of sedimentary organic carbon in the Lan-Yang Plain, northwestern Taiwan. West. Pacific Earth Sci. 3/1, 57-68.

Wei, K.-Y., Mii, H.-S., Huang, C.-Y., 2005. Age model and oxygen isotope stratigraphy of Site ODP 1202 in the southern Okinawa Trough, northwestern Pacific. Terrestr. Atmos. Oceanic Sci. 16, 1-17.

Xiang, R., Sun, Y., Li, T., Oppo, D.W., Chen, M., Zheng, F., 2007. Paleoenvironmental change in the middle Okinawa Trough since the last deglaciation: evidence from the sedimentation rate and planktonic foraminiferal record. Palaeogeogr. Palaeoclimatol. Palaeoecol. 243, 378-393.

Xu, X., Oda, M., 1999. Surface-water evolution of the eastern China Sea during the last 36,000 years. Mar. Geol. 156, 285-304.

Yancheva, G., Nowaczyk, N., Mingram, J., Dulski, P., Schettler, G., Negendank, J.F.W., Liu, J., Sigman, D.M., Peterson, L.C., Haug, G.H., 2007. Influence of the intertropical convergence zone on the East Asian monsoon. Nature 445, 74-77.

Yang, S.Y., Jung, H.S., Dhong, I.L., Li, C.X., 2003. A review on the provenance discrimination of sediments in the Yellow Sea. Earth Sci. Rev. 63, 93-120.

Yang, S.Y., Jung, H.-S., Li, C., 2004. Two unique weathering regimes in the Changjiang and Huanghe drainage basins: geochemical evidence from river sediments. Sediment. Geol. 164, 19-34.

Yi, S., Saito, Y., 2004. Latest Pleistocene climate variation of the east Asian monsoon from pollen records of two East China regions. Quat. Int. 121, 75-87.

Yu, H.S., Chow, J., 1997. Cenozoic basin in northern Taiwan and tectonic implications for the development of the eastern Asian continental margin. Palaeogeogr. Palaeoclimatol. Palaeoecol. 131, 133-144.

Zhao, M., Huang, C.-Y., Wei, K.-Y., 2005. A 28,000 year Uk 37 sea surface temperature record of ODP Site 1202B, Southern Okinawa Trough. Terrestr. Atmos. Oceanic Sci. $16,45-56$. 